\title{
Mapping the economic loss of ecosystem services
}

\section{caused by the invasive plant species Antigonon leptopus on the Dutch Caribbean Island of}

\section{St. Eustatius}

\author{
Seringe N. Huisman ${ }^{\ddagger}$, Wendy A. M. Jesse ${ }^{\ddagger}$, Jacintha Ellers ${ }^{\ddagger}$, Pieter J. H. van Beukering ${ }^{\S}$ \\ ‡ Department of Ecological Science, A-Life, Faculty of Science, Vrije Universiteit, Amsterdam, Netherlands \\ $\S$ Institute for Environmental Studies, Vrije Universiteit, Amsterdam, Netherlands
}

\author{
Corresponding author: Seringe N. Huisman (s.n.huisman@vu.nl), \\ Pieter J. H. van Beukering (pieter.van.beukering@vu.nl) \\ Academic editor: Benjamin Burkhard
}

Received: 11 Aug 2021 | Accepted: 24 Nov 2021 | Published: 13 Dec 2021

Citation: Huisman SN, Jesse WAM, Ellers J, van Beukering PJH (2021) Mapping the economic loss of ecosystem services caused by the invasive plant species Antigonon leptopus on the Dutch Caribbean Island of

St. Eustatius. One Ecosystem 6: e72881. https://doi.org/10.3897/oneeco.6.e72881

\begin{abstract}
Invasive species are a worldwide threat to biodiversity, especially on Caribbean islands. Through their impact on the structure and functioning of ecosystems, they also affect ecosystem services. Therefore, invasive species can have profound socio-economic effects. On the Dutch Caribbean Island of St. Eustatius, the invasive perennial vine Coralita is present on roughly $33 \%$ of the Island. While ecological damage is evident, effective management strategies are still lacking. This study links the ecological, cultural and societal effects of the invasion to the economy of the Island by estimating the ecosystem service losses due to Coralita in monetary value. We have spatially assessed the economic value of five main ecosystem services (tourism, non-use value, carbon sequestration, archaeology and local cultural and recreational value) to the different habitats on the Island and estimated the loss of these values under three scenarios of Coralita cover: $0 \%, 3 \%$ and $36 \%$ dominant cover. The baseline scenario of $0 \%$ demonstrated a total ecosystem service value of $\$ 2.7$ million per year, concentrated on the Quill volcano. The $3 \%$ and $36 \%$ scenario showed a yearly loss of $\$ 39,804$ and $\$ 576,704$,
\end{abstract}


respectively, with the largest losses located on the northern and eastern slopes of the Quill. These areas should be prioritised for management and the known potential gain per area enables choice of strategy, based on cost-benefit considerations. To reduce further economic loss by Coralita, we urgently advise an immediate management strategy and ongoing research into eradication and restoration methods.

\section{Keywords}

BES Islands, Coralita, economic value, invasive species, spatial assessment, scenario mapping

\section{Introduction}

Invasive species are a major threat to biodiversity worldwide (e.g. Mc Neely 2001,Bax et al. 2003). They are defined as non-native species that spread geographically and increase in abundance after establishment (Lodge and Shrader-Frechette 2003) and, by interfering with ecological processes and community dynamics, they can drastically alter the structure and functioning of an ecosystem (Yurkonis and Meiners 2004, Gandhi and Herms 2009, Chaffin et al. 2016). Examples of such effects are predation pressure, alteration of nutrient cycling and the spread of diseases (Ehrenfeld 2003, Crowl et al. 2008, Duron et al. 2017). Ecosystem changes are reflected in the provision of ecosystem services, which are defined as the contributions that ecosystems make to human well-being, distinct from the goods and benefits that people subsequently derive from them (Haines-Young and PotschinYoung 2018). They can be of cultural, social or economic importance (e.g. recreation, coastal protection, commodities). Invasive species can, therefore, have profound socioeconomic impacts (Pejchar and Mooney 2009). While the ecological impacts are well documented, fewer studies extend to the ecosystem service level (Peh et al. 2014, Walsh et al. 2016) and estimates of the economic costs associated with invasive species are limited (Pimentel et al. 2005, de Lange and van Wilgen 2010). Given the current increasing global trade connectivity and changes in land use and climate that facilitate the introduction and spread of invasive species, it has become of critical concern to understand the impact of invasive species on a multidisciplinary scale (Hulme 2009, Seebens et al. 2015, Bellard et al. 2016).

Small islands are especially susceptible to invasion (Gimeno et al. 2006, Dawson et al. 2017) and because their environment is strongly linked to the identity and economy of the island, invasive species tend to have a high socio-economic impact (Beukering et al. 2014). The perennial vine Antigonon leptopus, native to Mexico, is currently widespread across the Caribbean and classified as invasive on many islands (Invasive Species Compendium 2019). On St. Eustatius, one of the smallest inhabited Caribbean islands with a total area of $21 \mathrm{~km}^{2}$, A. leptopus has severely impacted ecological, societal and economic factors by being present in varying densities on roughly $33 \%$ of the Island (Berkowitz 2014). A. leptopus (hereafter called Coralita, its local name) was introduced on St. Eustatius as an ornamental plant in 1907 and started to spread during the 1980s (Ernst 
and Ketner 2007). A plausible cause was the drastic decline in agriculture practices during the $20^{\text {th }}$ century. Leaving bare land and free roaming livestock that intensively grazed on tree saplings, this change in land use provided suitable areas for invasion by (exotic) pioneer species (Burg et al. 2012, Jesse et al. 2020). Coralita grows very fast and reproduces both asexually through root tubers and sexually through seeds, which travel large distances via water and are produced through year-round flowering (Fig. 1) (Burke and DiTommaso 2017). These mechanisms allow Coralita to efficiently spread and invade new areas, where it eventually kills native vegetation through smothering, light competition and inhibition of fruiting and germination (Fig. 1). It also poses a threat to animal species, such as iguanas and birds by reducing suitable habitat and smothering available nesting sites (Clavero et al. 2009, Berkowitz 2014). Despite several studies and reports emphasising the need to control this species, official management strategies are still lacking (Ernst and Ketner 2007, Berkowitz 2014, Overeem and Riemens 2018).
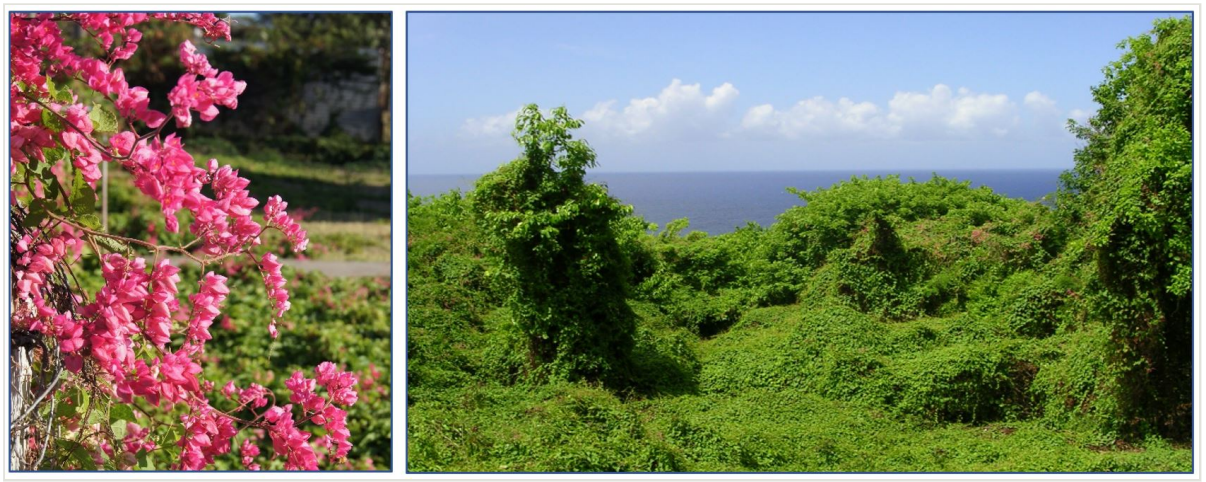

Figure 1.

Coralita flowers (left panel) and vegetation structure of Coralita on the Island of St. Eustatius (right panel) (Ernst and Ketner 2007, Jesse et al. 2020).

To address the full scope of damage caused by Coralita on St. Eustatius, a multidisciplinary approach that links the ecological impacts to the socio-economic status of the Island is needed. While social and ecological impacts of Coralita have received scientific attention (e.g. Burke and DiTommaso 2017, van Andel et al. 2016, Heger and van Andel 2019), the economic impact remains unstudied. St. Eustatius' economy is nowadays largely dependent on tourism and, therefore, the natural environment that attracts tourists is highly important for the Islands' prosperity (Polman et al. 2016). Expressing the negative effects of Coralita in monetary value provides an explicit measure of the problem, which likely encourages the willingness to act. The total economic value (TEV) of nature on St. Eustatius (marine and terrestrial) is estimated to be $\$ 25.5$ million (USD) per year, based on eight ecosystem services (Cado van der Lely et al. 2014). With the current environmental pressures and no additional management, the TEV is also expected to decline to $\$ 20.2$ million annually within 30 years (Cado van der Lely et al. 2014). The main pressures identified were tourism and free-roaming livestock, but the study did not include the threat of Coralita to the ecosystem. Since invasive species have shown to cause substantial 
economic loss, for example, an estimated $\$ 120$ billion yearly in the United States (Pimentel et al. 2005) and \$423 million per year in South Africa (de Lange and van Wilgen 2010), including the effects of Coralita is essential when predicting the economic loss of ecosystem services on St. Eustatius.

The aim of this study was to map the supply of the main terrestrial ecosystem services and assess the loss of economic value under different scenarios of Coralita cover on St. Eustatius. We included five ecosystem services in our study (tourism value, non-use value, carbon sequestration value, archaeological value and the local cultural and recreational value, which are explained under the Common International Classification of Ecosystem Services in the methods section) and determined the total annual economic value, the spatial distribution of values on the Island and the loss of these values due to Coralita presence. The amount of total loss demonstrated the urgency to control the Coralita invasion and, by identifying where the highest losses occurred under different scenarios of Coralita cover, we identified priority areas for management.

\section{Materials and methods}

\section{Study site}

The Island of St. Eustatius is part of the Lesser Antilles, which are located in the Caribbean Sea (Fig. 2). Together with Bonaire and Saba, it is part of the Caribbean Netherlands, bearing the status of special Dutch Municipality. With $21 \mathrm{~km}^{2}$ and 3,100 inhabitants (CBS 2019), it is one of the smallest Lesser Antillean Islands. The climate is seasonal, with a dry period from December to April and a wet period between August and November. The annual mean precipitation, although highly variable, is $986 \mathrm{~mm}$. The dry season has a daily mean temperature of $24^{\circ} \mathrm{C}$, while temperatures rise to over $30^{\circ} \mathrm{C}$ during the wet season (NOAA 2015). The Island is of volcanic origin, with extinct volcanoes in the north that nowadays form the hills of Boven National Park and the characteristic Quill volcano in the south. The Quill is a dormant volcano that last erupted 1600 years ago, leaving a $750 \mathrm{~m}$ wide crater on top of the $600 \mathrm{~m}$ high cone. Today the Quill National Park is a popular hiking destination, with scenic views from trails up to the crater rim. The central area of the Island, called the Cultuurvlakte, is flat and urbanised. Oranjestad, the only town on the Island, is spread from the centre of the Cultuurvlakte to the west coast. Despite the small size of the Island, the diversity of the landscape and climate accounts for a variety of vegetation types. The Quill volcano, which receives the highest rainfall, is covered by tropical forest, while other areas have dry, shrubby bush vegetation (de Freitas et al. 2012). The Island harbours at least ten species that are endemic to the Islands of St. Maarten, Saba and St. Eustatius (Bos et al. 2018) and the critically-endangered Lesser Antillean iguana (Iguana delicatissima), that is endemic to the Lesser Antilles (IUCN Red List 2018).

St. Eustatius was once known as the 'Golden Rock', as it was an important international trading centre in the Caribbean during the $17^{\text {th }}$ and $18^{\text {th }}$ century. This period largely contributed to the rich archaeology of the Island: with an estimated 200 sites on land and 200 shipwrecks in the surrounding waters, St. Eustatius has the highest concentration of 
archaeological sites of the New World (Stelten 2009). The economy of the Island is currently driven by tourism, oil industry and the government (Chamber of Commerce \& Industry 2016). The Gross Domestic Product (GDP) of the Island was 100 million USD in 2016 (CBS 2018) and has remained relatively stable over the past five years. Tourism started to develop from 1965 onwards, when agricultural practices were abandoned and infrastructure improved. Major developments were the opening of the airport in 1971 and the establishment of the NuStar oil terminal in 1982, resulting in NuStar being the largest private employer on the island (Chamber of Commerce \& Industry 2016). Tourists mainly visit the Island to dive and snorkel on the relatively healthy surrounding coral reefs and to hike the trails of the Quill volcano (Kerkhof et al. 2014).
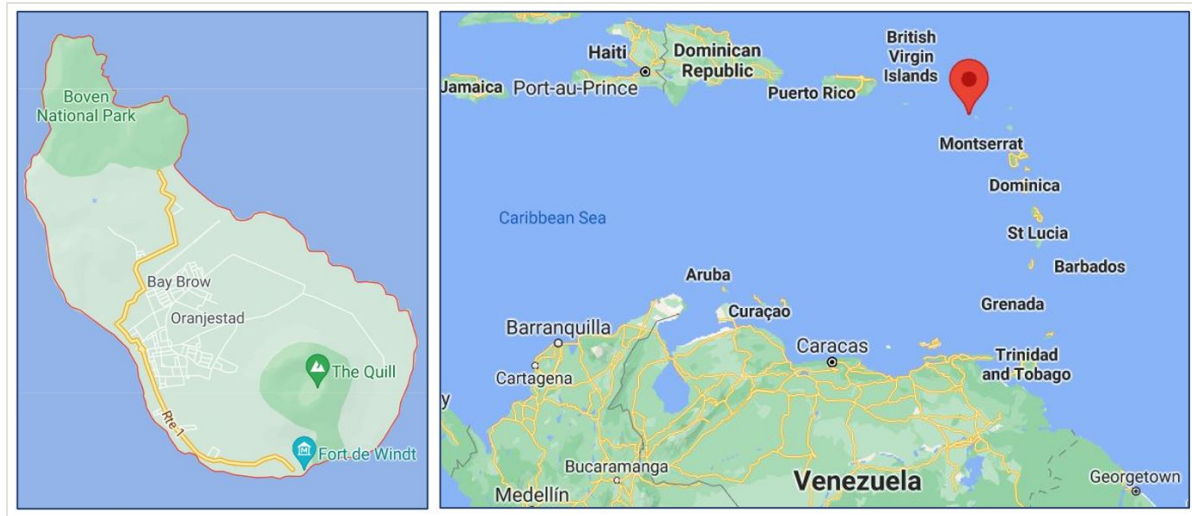

Figure 2.

Map of St. Eustatius including the National Park areas of Boven and the Quill volcano (dark green) (left panel) and its location in the Caribbean Sea (red marker) (right panel). (Source: Google Maps)

\section{General overview}

This section provides a short overview of the mapping steps performed in ArcGIS Desktop 10.6.1. Details on the data sources and calculations are outlined in the following sections.

We started with a base map that divided the Island into sub-areas, based on vegetation types, to which we could spatially assign the ecosystem service values. After constructing the ecosystem service maps, which required extra data layers depending on the ecosystem service, each ecosystem service map was overlaid with the Coralita cover scenarios. This enabled calculation of the percentage Coralita cover per area. Subsequently, the ecosystem service value losses per area were calculated, based on the assumed reduction of ecosystem services caused by Coralita. The values for each area were expressed in USD (2019) per hectare per year (\$/ha/yr). Fig. 3 gives a schematic overview of these steps. 


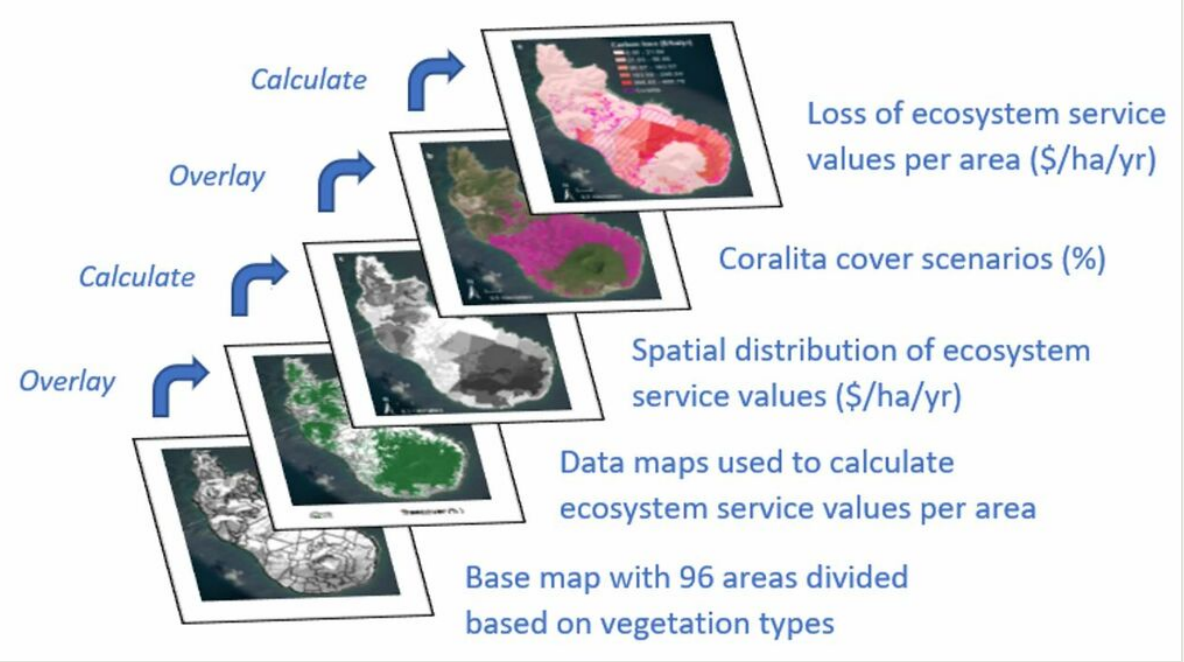

Figure 3.

Schematic overview of the general steps of the mapping methodology used to calculate and map the loss of ecosystem service values due to Coralita presence on St. Eustatius. The data maps used to build the ecosystem service layers differ per ecosystem service. The overlay of each Coralita cover scenario with the ecosystem service layers resulted in a map of the loss of ecosystem service values. Units are percentage $(\%)$ and USD per hectare per year (\$/ha/yr).

\section{Base maps}

The basis of all ecosystem service layers was a polygon feature layer that divided the Island into sub-areas, which we used to calculate and visualise the ecosystems service values per geographic region across the Island. The areas were based on vegetation types, resulting from an extensive vegetation survey by de Freitas et al. (2012). They described 13 different vegetation types, represented in $\sim 60$ sub-areas across the Island. The Cultuurvlakte was classified as 'urban' and not divided into sub-areas. Tieskens et al. (2014) used this map to spatially allocate several ecosystem services that they derived from other studies. They further divided the Cultuurvlakte into sub-areas, mostly according to urban borders, such as roads. We used the same map in this study, but we detected a geographical reference shift in south-western direction, which we adjusted based on the ArcGIS World Imagery maps via the Edge Matching tool (Spatial Adjustment toolbox). Furthermore, we deleted all polygons without vegetation description that were smaller than $10 \mathrm{~m}^{2}$ via the Eliminate tool (Data Management toolbox) because they appeared to be slivers of the vegetation polygons. This resulted in a feature layer with 96 polygons (subareas) to which the different ecosystem service values were assigned (Fig. 4). The polygons ranged from 0.12 to 129 hectares, except for the hills in Boven, which formed one connected sub-landscape spanning 298 hectares. To visualise the Island's topography in the final figures (Figs. 6-8), we used a grey-scale elevational layer with hill shading effect and two layers with the Island's main roads and buildings below the semi-transparent ecosystem service layers. All maps had XY Coordinate System 
WGS_1984_UTM_Zone_20N and world satellite images were used as a background in Figs. 4-8 (Source: Esri, DigitalGlobe, GeoEye, Earthstar Geographics, CNES/Airbus DS, USDA, USGS, AeroGRID, IGN and the GIS User Community).

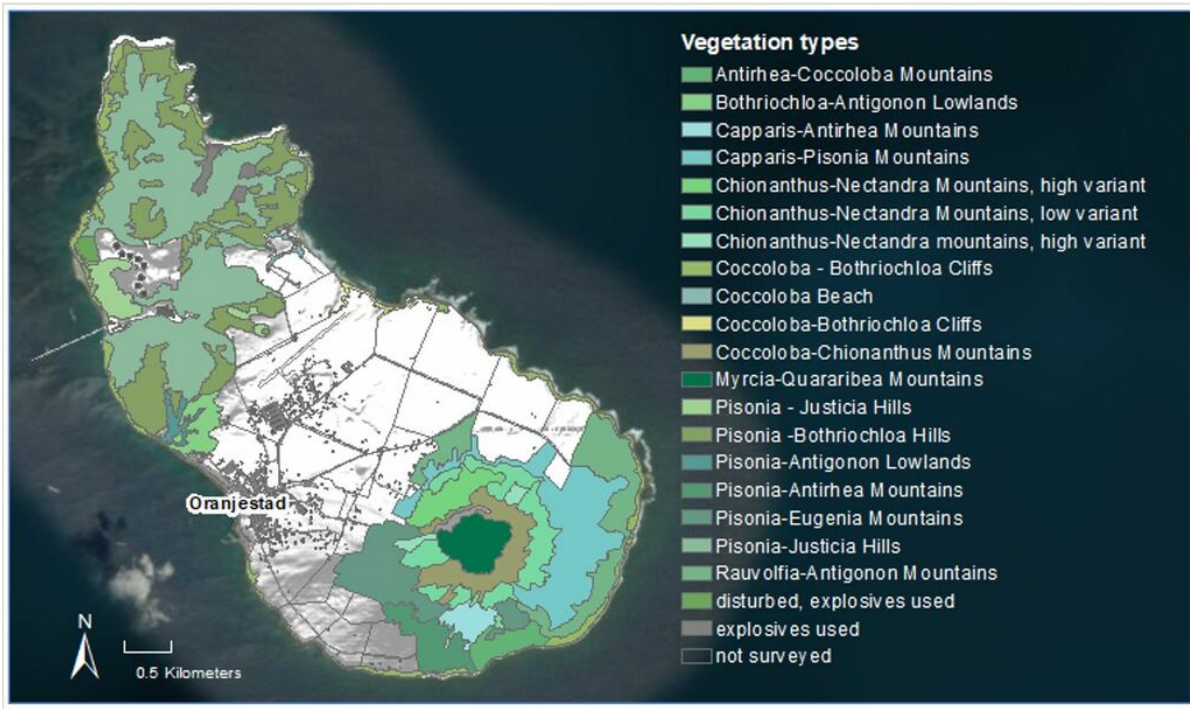

Figure 4.

Vegetation map of St. Eustatius derived from de Freitas et al. (2012), with additional polygons to divide the Cultuurvlakte (Tieskens et al. 2014) and adjusted for the purpose of this study.
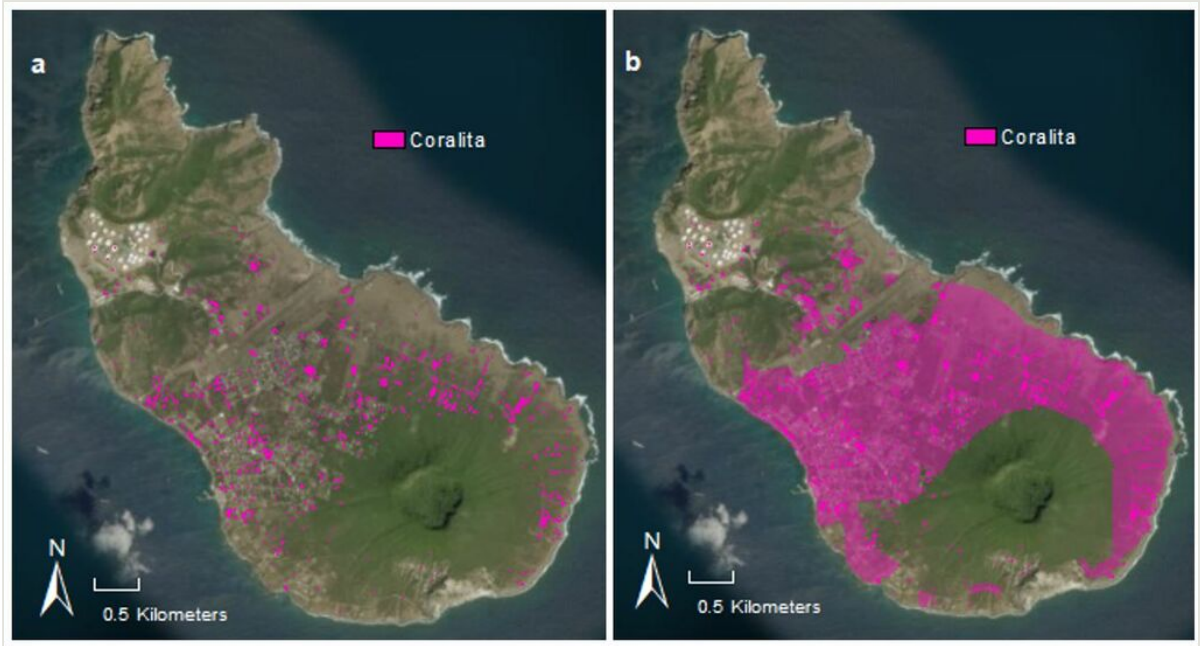

Figure 5.

Dominant Coralita cover scenarios of 3\% (a) (derived from Haber et al. (2021)) and 36\% (b) on the Island of St. Eustatius. The conglomerate of white buildings in the northern hills is the NuStar oil terminal. 


\section{Coralita cover scenarios}

The analyses were based on three scenarios of Coralita cover, expressed in percentage cover of the Island's total surface area: $0 \%$ (absence of Coralita), 3\% dominant cover (Fig. $5 a$ ) and $36 \%$ dominant cover (Fig. 5b).

The $0 \%$ scenario illustrates the situation before Coralita invasion, as well as the hypothetical scenario of complete Coralita removal and ecosystem restoration in the future. The ecosystem service values in this scenario represent the potential economic value of ecosystem services unaffected by Coralita. Most of the data used for this baseline scenario stem from recent years when Coralita was already present; however, we carefully considered whether the obtained values were affected by the Coralita presence at that time, for example, when the archaeological value was based on expenditures from tourists visiting archaeological sites and the sites were not covered in Coralita at that time, we assumed no effect on the value.

The $3 \%$ scenario was based on remote sensing of dominant Coralita cover in 2014 by Haber et al. (2021). Focusing on dominant cover, the 3\% scenario captured hotspots of densely present Coralita only, excluding the larger area of subdominant invasion. Most patches were located on the Cultuurvlakte and around the north-eastern slopes of the Quill volcano (Fig. 5a).

The $36 \%$ scenario was based on the observed Coralita presence by Berkowitz (2014). Visually, Coralita was estimated to cover $33 \%$ of the entire Island. Although this range included subdominant cover, the dominant patches are likely to expand within that range. Therefore, we combined the Berkowitz range and the $3 \%$ scenario patches into one map using the Mosaic To New Raster tool (Data management toolbox), which added up to 36\% cover. In this way, we established a $36 \%$ dominant cover future scenario. Given the estimated Coralita range expansion of approximately 50\% between 2007 and 2014, this scenario is realistically reached if no rigorous measures are taken. In this scenario, the Cultuurvlakte is almost entirely invaded by Coralita and dominant cover progresses upslope on the northern and eastern flanks of the Quill (Fig. 5b).

\section{Data resources}

\section{Ecosystem service values and losses per Coralita cover scenario}

The terrestrial ecosystem services used in this study were tourism, non-use value, carbon sequestration, archaeology and local cultural and recreational value. The choice of ecosystem services was based on data availability and prior identification of the most valuable ecosystem services on the Island (Cado van der Lely et al. 2014, Kerkhof et al. 2014, Tieskens et al. 2014). Although the ecosystem services included in this paper are based on the internationally-recognised Common International Classification of Ecosystem Services (CICES) (Haines-Young and Potschin-Young 2018), we labelled them with more intuitive and familiar names in order to allow non-experts in the ecosystem services terminology and local decision-makers to straightforwardly comprehend the meaning of the 
studied ecosystem services. The ecosystem service tourism is attributed to visitors and refers to the CICES section Cultural (biotic) - experiential and physical use (code 3.1.1.1 and 3.1.1.2). The non-use value is held by Dutch citizens in Europe and refers to the CICES section Cultural (biotic) - existence (code 3.2.2.1). Carbon sequestration serves the global community and refers to the CICES section Regulation \& Maintenance (biotic) (code 2.2.6.1). The local cultural and recreational value (hereafter referred to as local value) is the benefit to the local community and refers to the CICES section Cultural (biotic) (code 3.1.1.1). Archaeology is the only cultural ecosystem service that falls in the CICES extended section of abiotic services and refers to direct, in-situ and outdoor interactions with natural physical systems that depend on presence in the abiotic environmental setting. It includes intellectual and representative interactions with abiotic components of the natural environment, such as ruins and ancient artefacts that have either an existence or bequest value (codes 6.1.2.1 and 6.2.2.1).

The economic value maps of three ecosystem services were extracted from an earlier study by Tieskens et al. (2014) (tourism, archaeology and local value; downloaded from the Dutch Caribbean Biodiversity Database (https://www.dcbd.nl/document/economicvalue-terrestrial-ecosystem-st-eustatius) and two were newly constructed for the purpose of this study (carbon sequestration and non-use value). The configuration of the value, the valuation method and the method of spatial allocation to the Island differed per ecosystem service. Table 1 gives an overview of these factors, which are further explained in the following sections. It also includes the loss of each ecosystem service value that we determined for the $3 \%$ and $36 \%$ Coralita cover scenarios, expressed in percentage reduction of the initial ecosystem service values under the $0 \%$ Coralita cover scenario. After determining the percentage Coralita cover per area using the Zonal Statics tools (Spatial Analyst toolbox), the reductions were calculated via the Field Calculator. The spatially distributed values were expressed in USD per hectare per year ( $\$ / \mathrm{ha} / \mathrm{yr})$, rounded off for clarity in the text. All values were corrected for inflation to USD (2019) (CBS 2019), including the calculated values referred to as USD or $\$$ hereafter.

Table 1.

Overview of background data, allocation and valuation methods used to determine the spatial distribution of the loss of ecosystem service values under different scenarios of dominant Coralita cover on St. Eustatius. Abbreviations: CICES = Common International Classification of Ecosystem Services; WTP = willingness to pay; BES Islands = Bonaire, St. Eustatius and Saba.

\begin{tabular}{|c|c|c|c|c|c|}
\hline & Tourism & Non-use value & $\begin{array}{l}\text { Carbon } \\
\text { sequestration }\end{array}$ & Archaeology & Local value \\
\hline $\begin{array}{l}\text { CICES } \\
\text { section }\end{array}$ & $\begin{array}{l}\text { Cultural (biotic) } \\
\text { - experiential } \\
\text { and physical } \\
\text { use (3.1.1.1 } \\
\text { and 3.1.1.2) }\end{array}$ & $\begin{array}{l}\text { Cultural (biotic) - } \\
\text { existence (3.2.2.1) }\end{array}$ & $\begin{array}{l}\text { Regulation \& } \\
\text { Maintenance } \\
\text { (biotic) (2.2.6.1) }\end{array}$ & $\begin{array}{l}\text { Cultural (abiotic) (6.1.2.1 } \\
\text { and 6.2.2.1). }\end{array}$ & $\begin{array}{l}\text { Cultural } \\
\text { (biotic) - } \\
\text { experiential } \\
\text { use (3.1.1.1) }\end{array}$ \\
\hline
\end{tabular}




\begin{tabular}{|c|c|c|c|c|c|}
\hline & Tourism & Non-use value & $\begin{array}{l}\text { Carbon } \\
\text { sequestration }\end{array}$ & Archaeology & Local value \\
\hline $\begin{array}{l}\text { Value } \\
\text { composition }\end{array}$ & $\begin{array}{l}\text { Tourist } \\
\text { expenditures + } \\
\text { WTP of } \\
\text { tourists for } \\
\text { nature on St. } \\
\text { Eustatius }\end{array}$ & $\begin{array}{l}\text { WTP of Dutch } \\
\text { mainland } \\
\text { inhabitants for } \\
\text { nature on St. } \\
\text { Eustatius }\end{array}$ & $\begin{array}{l}\text { Market price of } \\
\text { the amount of } \\
\text { carbon } \\
\text { sequestered by } \\
\text { St. Eustatius' } \\
\text { forests }\end{array}$ & $\begin{array}{l}\text { Tourist expenditures }+ \\
\text { WTP of tourists and local } \\
\text { inhabitants for } \\
\text { management of } \\
\text { archaeological sites }\end{array}$ & $\begin{array}{l}\text { WTP of local } \\
\text { inhabitants for } \\
\text { nature } \\
\text { conservation }\end{array}$ \\
\hline $\begin{array}{l}\text { Valuation } \\
\text { method }\end{array}$ & $\begin{array}{l}\text { Tourist exit } \\
\text { survey with } \\
\text { Choice } \\
\text { Experiment }\end{array}$ & $\begin{array}{l}\text { Contingent } \\
\text { Valuation and } \\
\text { Choice } \\
\text { Experiment } \\
\text { amongst Dutch } \\
\text { mainland } \\
\text { inhabitants }\end{array}$ & $\begin{array}{l}\text { Calculated with } \\
\text { tree cover data } \\
\text { and carbon } \\
\text { fixation rate of } \\
\text { tropical dry forest }\end{array}$ & $\begin{array}{l}\text { Tourist exit survey and } \\
\text { household survey, both } \\
\text { with Choice Experiment }\end{array}$ & $\begin{array}{l}\text { Household } \\
\text { survey with } \\
\text { Choice } \\
\text { Experiment }\end{array}$ \\
\hline $\begin{array}{l}\text { Valuation } \\
\text { sources }\end{array}$ & $\begin{array}{l}\text { Kerkhof et al. } \\
(2014)\end{array}$ & $\begin{array}{l}\text { Beukering et al. } \\
\text { (2012)(WTP all } \\
\text { BES Islands), } \\
\text { share St. } \\
\text { Eustatius derived } \\
\text { in this study }\end{array}$ & $\begin{array}{l}\text { Calculated in this } \\
\text { study }\end{array}$ & $\begin{array}{l}\text { Kerkhof et al. (2014) } \\
\text { (tourists), Fenkl et al. } \\
\text { (2014) (local inhabitants) }\end{array}$ & $\begin{array}{l}\text { Fenkl et al. } \\
(2014)\end{array}$ \\
\hline $\begin{array}{l}\text { Spatial } \\
\text { allocation }\end{array}$ & $\begin{array}{l}\text { Along hiking } \\
\text { trails (Tieskens } \\
\text { et al. 2014) }\end{array}$ & $\begin{array}{l}\text { Based on } \\
\text { biodiversity } \\
\text { distribution } \\
\text { determined in this } \\
\text { study }\end{array}$ & $\begin{array}{l}\text { Based on tree } \\
\text { cover distribution } \\
\text { used in this } \\
\text { study }\end{array}$ & $\begin{array}{l}\text { Following probability } \\
\text { map of archaeological } \\
\text { findings by ARGEOgraph } \\
\text { (Tieskens et al. 2014) }\end{array}$ & $\begin{array}{l}\text { Based on } \\
\text { accessible } \\
\text { forest areas ( } \\
\text { Tieskens et al. } \\
\text { 2014) }\end{array}$ \\
\hline $\begin{array}{l}\text { Map layers } \\
\text { (ArcGIS) } \\
\text { excluding } \\
\text { base layers }\end{array}$ & $\begin{array}{l}\text { Tourism value } \\
\text { (Tieskens et al. } \\
\text { 2014) }\end{array}$ & $\begin{array}{l}\text { Tree cover, iguana } \\
\text { sightings, } \\
\text { important birding } \\
\text { areas, turtle } \\
\text { nesting sites and } \\
\text { endemic plant } \\
\text { layers, adding up } \\
\text { to one biodiversity } \\
\text { layer used to } \\
\text { create non-use } \\
\text { value layer }\end{array}$ & $\begin{array}{l}\text { Tree cover layer } \\
\text { used to create } \\
\text { carbon } \\
\text { sequestration } \\
\text { layer }\end{array}$ & $\begin{array}{l}\text { Archaeology value ( } \\
\text { Tieskens et al. 2014) }\end{array}$ & $\begin{array}{l}\text { Local value ( } \\
\text { Tieskens et al. } \\
\text { 2014) }\end{array}$ \\
\hline $\begin{array}{l}\text { Value loss for } \\
\text { Coralita } \\
\text { covered areas } \\
\text { under } 3 \% \\
\text { scenario }\end{array}$ & $33 \%$ & $100 \%$ & $80 \%$ & $100 \%$ & $100 \%$ \\
\hline $\begin{array}{l}\text { Value loss for } \\
\text { Coralita } \\
\text { covered areas } \\
\text { under } \\
36 \% \text { scenario }\end{array}$ & $77 \%$ & $100 \%$ & $80 \%+30 \%$ & $100 \%$ & $100 \%$ \\
\hline
\end{tabular}




\section{Tourism}

The tourism value attributable to nature was derived from Kerkhof et al. (2014) and mapped according to Tieskens et al. (2014). The value was composed of tourist expenditures (revenues of the tourism sector, dependent on nature) and the willingness to pay (WTP) of tourists for conservation of the natural environment on the Island. This WTP, obtained through an extensive choice experiment, was used as a proxy for how highly people value the ecosystem (Kerkhof et al. 2014). The total value related to terrestrial nature was $\$ 1.2$ million per year. This value was spatially distributed on the Island along the hiking trails, because the terrestrial nature is mostly enjoyed by hiking the trails in the National Park areas. The trails up the Quill volcano are especially popular with tourists. The tourism values were weighted by the trails' popularity and included a 200-metre radius around the trails (Tieskens et al. 2014).

To determine the loss of tourism value under the $3 \%$ Coralita scenario, we assumed a complete loss of WTP by tourists for the places with dominant Coralita cover, because a degraded habitat dominated by one species is likely not considered worth conserving. However, we did not expect the overall expenditure of tourists to decline yet, since the patchiness of this scenario still provides plenty of uninvaded habitat along the trails that tourists are hiking. Therefore, it was assumed that tourists were visiting these areas equally often. Besides, the $3 \%$ scenario reflects the minimum dominant cover situation in 2014, when there was no evidence of tourism decline due to Coralita presence. The proportion WTP from the total value was $33 \%$, the other $67 \%$ reflected expenditures. Hence, the tourism value was reduced with $33 \%$ in areas that were dominantly covered by Coralita under the $3 \%$ scenario.

For the $36 \%$ cover scenario, we assumed the same decline to zero for the WTP (33\% from the total value), plus an additional loss in expenditure. We expected the large areas of dominant Coralita cover in this scenario to discourage tourists to hike the trails, because the beautiful and diverse scenery that they were previously enjoying would largely be replaced by a monoculture of Coralita. In the study by Kerkhof et al. (2014), scores given by tourists for how much they enjoyed the features of 'natural landscape' and 'hiking' made up $65 \%$ of the maximum 'enjoyability score'. Assuming a full decline of these scores because a Coralita-dominated landscape is not likely to be enjoyed by tourists, we calculated a loss of $65 \%$ from $67 \%$ (the share of expenditures in the total value). In addition to the $33 \%$ decline to zero of the WTP, this resulted in an overall $77 \%$ loss of tourism value for the areas with dominant Coralita cover under the $36 \%$ scenario.

\section{Non-use value}

The non-use value reflects the value of importance assigned to nature through the willingness to conserve the ecosystem. It is often considered a biodiversity value, referring to the richness of nature and its perception by people. In contrast to the other ecosystem services, it is not based on goods directly provided by the ecosystem and used by people. In this case, the non-use value is defined by the willingness to pay (WTP) of Dutch mainland inhabitants for the conservation of nature on St. Eustatius. Beukering et al. 
(2012) determined the WTP from Dutch inhabitants for nature on the BES Islands (Bonaire, St. Eustatius and Saba) through a combination of contingent valuation methods and choice experiments. Nature in this experiment included the terrestrial and marine ecosystems of all three Islands and yielded a total non-use value of \$20 million per year.

To derive the value for terrestrial nature only from the total WTP value that included both marine and terrestrial nature, we assumed that one third was attributable to terrestrial nature and two thirds to the marine areas. This assumption was based on the emphasis on the marine habitat in the choice experiment (i.e. the graphic illustration of BES nature showed an underwater scenery) and because all Islands are relatively small compared to their vast surrounding marine areas. The individual portion of the total non-use value associated with St. Eustatius was determined by its proportion of the total terrestrial surface area of the three Islands. Bonaire is much larger than St. Eustatius and Saba (288 $\mathrm{km}^{2}, 21 \mathrm{~km}^{2}$ and $13 \mathrm{~km}^{2}$, respectively), but St. Eustatius and Saba harbour more natural habitat. Therefore, we rounded off St. Eustatius' share of $7 \%$ in surface area to $10 \%$. This resulted in a total non-use value for terrestrial nature on St. Eustatius of $\$ 680,410$ per year.

The total non-use value was mapped according to a biodiversity score system that we developed for this study. Every polygon received a summed score based on five indicators that we chose, based on their importance to biodiversity and data availability: tree cover, endemic iguana presence, the occurrence of endemic plants, sea turtle nesting sites and important birding areas. Mean tree cover (Suppl. material 1) (Hansen et al. 2013) was divided into low, medium and high forest cover $(<20 \%, 20-60 \%$ and $>60 \%$, respectively) and scored accordingly, because dense tropical forests harbour higher genetic diversity and species richness (Wilson et al. 2012). We included iguana presence, based on an iguana sightings map downloaded from the Dutch Caribbean Biodiversity Database (https://www.dcbd.nl/document/iguana-sightings-st-eustatius) (Suppl. material 2). With their critically endangered status, they are close to manifesting a major loss in biodiversity (Burg et al. 2012). Important birding areas were also included through the Dutch Caribbean Biodiversity Database (https://www.dcbd.nl/document/important-bird-areas-caribbean-steustatius) (Suppl. material 3). The presence of the critically-endangered turtle species (Mortimer and Donnelly 2008) was scored, based on the beaches where they nest (Esteban et al. 2018) and the endemic and iconic Statia Morning Glory (Ipomoea sphenophylla) occurrence was derived from a distribution map by Leeuw (2014) (Suppl. material 4). The summed scores were weighted by the size of the sub-area where they occurred and standardised to relative scores, allowing us to assign each polygon a proportion of the total monetary non-use value and establish the values in $\$ / \mathrm{ha} / \mathrm{yr}$.

To calculate the reduction in non-use value under the $3 \%$ and $36 \%$ Coralita cover scenarios, we assumed the WTP to be zero for the dominantly-covered areas. A dominant Coralita system quickly loses its biodiversity, degrading the area to a poor ecosystem that likely no-one is willing to pay for (Burke and DiTommaso 2017). Coralita affects all biodiversity factors that we used to map the non-use value, i.e. by degrading habitat and smothering nesting sites (of birds, iguanas and turtles) and overgrowing endemic plants. Therefore, non-use values were reduced by $100 \%$ for the dominantly covered areas under both Coralita cover scenarios. 


\section{Carbon sequestration}

Carbon sequestration is considered a regulating ecosystem service function because it reflects the capture and storage of carbon from the atmosphere (Haines-Young and Potschin-Young 2018). To define the value of carbon captured by the forests on St. Eustatius, mean tree cover in hectares (ha) was calculated for each polygon. Mean tree cover was based on remotely-sensed canopy data by Hansen et al. (2013) (Suppl. material 1). Carbon sequestration values can be directly derived from the net primary productivity (NPP), which reflects the net carbon gain by plants (Chapin and Eviner 2014). The NPP of tropical dry forest is estimated to be 8-21 metric tonnes (megagram) per hectare per year $(\mathrm{Mg} / \mathrm{ha} / \mathrm{yr}$ ), which is slightly lower than for tropical wet forest (13-28 Mg/ha/yr) (Murphy and Lugo 1986). As the forests on St. Eustatius are relatively wet dry forests (van Andel et al. 2016), we used $21 \mathrm{Mg} / \mathrm{ha} / \mathrm{yr}$ multiplied by the tree cover area (ha) to calculate the amount of carbon per polygon. The European Union Emissions Trading System (EU ETS) April 2019 price of $\$ 24.86$ per metric tonne was used to calculate the monetary value of carbon per polygon in \$/ha/yr. As the April 2019 price was similar to the 2019 average carbon price $(\$ 25)$, the results were unaffected by short term market fluctuations. We used the market price instead of the more holistic social costs of carbon, because our study aims to guide local decision-makers in their efforts to manage their ecosystems in rather constrained conditions with limited budgets. By adopting the market value of carbon, a more financially realistic picture is presented in which these policy-makers could theoretically even try to sell the generated carbon credits on the global market. Moreover, van den Bergh and Botzen (2015) state that, in view of the many uncertainties and omissions in current costbenefit analyses of climate impacts and the social costs of carbon, alternative approaches, such as using the market value, should be considered.

The loss of carbon sequestration value under the $3 \%$ Coralita cover scenario was calculated by assuming $80 \%$ reduction for the areas covered in Coralita, based on the study of van der Heijden et al. (2015) that assessed the carbon sequestration reduction of forests covered in lianas. The remaining $20 \%$ reflects carbon sequestration through the few uncovered parts of the trees and by Coralita itself, a plant that captures a minimal amount of carbon compared to trees because of its much lower biomass (De Deyn et al. 2008).

For the $36 \%$ Coralita cover scenario, we expected more impact on the carbon sequestration value. With vast continuous areas of dominant Coralita cover, eventual death of trees is a likely result, causing a release of carbon into the atmosphere (Tyukavina et al. 2018). Instead of capturing carbon and functioning like a carbon sink, these spots can then become a carbon source (Baccini et al. 2017). We estimated this to happen to $30 \%$ of the trees, considering that not all trees are equally susceptible and that varying factors, such as soil conditions, can enhance local resilience (Burslem and Whitmore 1999). This $30 \%$ was added to the assumed $80 \%$ reduction for the dominantly covered areas under the $36 \%$ Coralita scenario. 


\section{Archaeology}

Archaeological sites and potential archaeological findings in the landscape provide an important economic value. The rich (pre)history of trade and colonisation by Amerindians and, later, by Europeans and Africans, has led to high probabilities of finding archaeological artefacts and current public archaeological sites are frequently visited by tourists. The archaeology value of St. Eustatius, derived from the mapping report of Tieskens et al. (2014), consisted of these tourist expenditures and the WTP of tourists and local inhabitants to manage archaeological sites. The WTP values were obtained through the same choice experiments as the WTP for nature that determined the non-use and local value (Kerkhof et al. 2014, Fenkl et al. 2014). The total archaeological value of $\$ 285,445$ was spatially distributed based on a probability map of expected archaeological findings by ARGEOgraph (ARGEOgraph 2013, Tieskens et al. 2014).

The loss of archaeological value for dominant Coralita cover was assumed to be $100 \%$, because Coralita easily overgrows any type of archaeological site. The expenditure from visiting archaeological sites will inarguably decline if they become invisible due to smothering by Coralita and WTP for archaeology is equally likely to fall when there are no visible sites left and potential excavation is hampered by Coralita presence. Therefore, a complete loss or archaeology value was calculated for the dominant Coralita areas under both scenarios.

\section{Local cultural and recreational value}

The local cultural and recreational value (also referred to as local value) reflects the importance of the natural environment to the local inhabitants, reflected by their willingness to pay (WTP) for conservation or improvement of this environment. Fenkl et al. (2014) designed a survey to gain insight into the activities and engagement of local people related to the natural environment, including a choice experiment that demonstrated their WTP for nature conservation. Based on the number of households and the WTP derived from the survey, the total value reserved for nature conservation by the local people was estimated to be $\$ 41,315$. This value was spatially distributed in relation to accessible forest areas, assuming that these areas serve as the most important enjoyable nature areas to the local inhabitants and, thus, are the areas they are most willing to pay for when it comes to conservation (Tieskens et al. 2014).

Table 2.

Total annual value of ecosystem services in USD (2019) for the $0 \%$ Coralita cover scenario and total annual loss of ecosystem service values under the $3 \%$ and $36 \%$ Coralita cover scenarios on the Island of St. Eustatius.

\begin{tabular}{|l|l|l|l|}
\hline Ecosystem service & $\begin{array}{l}\text { Total annual value } \mathbf{0 \%} \\
\text { scenario }\end{array}$ & $\begin{array}{l}\text { Total annual loss } \mathbf{3} \% \\
\text { scenario }\end{array}$ & $\begin{array}{l}\text { Total annual loss 36\% } \\
\text { scenario }\end{array}$ \\
\hline Tourism value & $\$ 1,231,310$ & $\$ 3,858$ & $\$ 111,545$ \\
\hline Non-use value & $\$ 751,298$ & $\$ 18,016$ & $\$ 212,472$ \\
\hline
\end{tabular}




\begin{tabular}{|l|l|l|l|}
\hline Ecosystem service & $\begin{array}{l}\text { Total annual value } \mathbf{0 \%} \\
\text { scenario }\end{array}$ & $\begin{array}{l}\text { Total annual loss } \mathbf{3} \% \\
\text { scenario }\end{array}$ & $\begin{array}{l}\text { Total annual loss 36\% } \\
\text { scenario }\end{array}$ \\
\hline $\begin{array}{l}\text { Carbon } \\
\text { sequestration }\end{array}$ & $\$ 410,625$ & $\$ 8,292$ & $\$ 132,744$ \\
\hline Archaeology value & $\$ 285,445$ & $\$ 8,416$ & $\$ 105,542$ \\
\hline Local value & $\$ 41,315$ & $\$ 1,222$ & $\$ 14,401$ \\
\hline Total & $\$ 2,719,993$ & $\$ 39,804$ & $\$ 576,704$ \\
\hline
\end{tabular}

For both Coralita cover scenarios, the local cultural and recreational value was expected to decline to zero. Most local people are fully aware of the negative impacts of Coralita and they have indicated strong 'unwantedness' of its presence (Vaas et al. 2017). Consequently, the local value loss was calculated to be $100 \%$ for the areas of dominant cover under both Coralita cover scenarios.
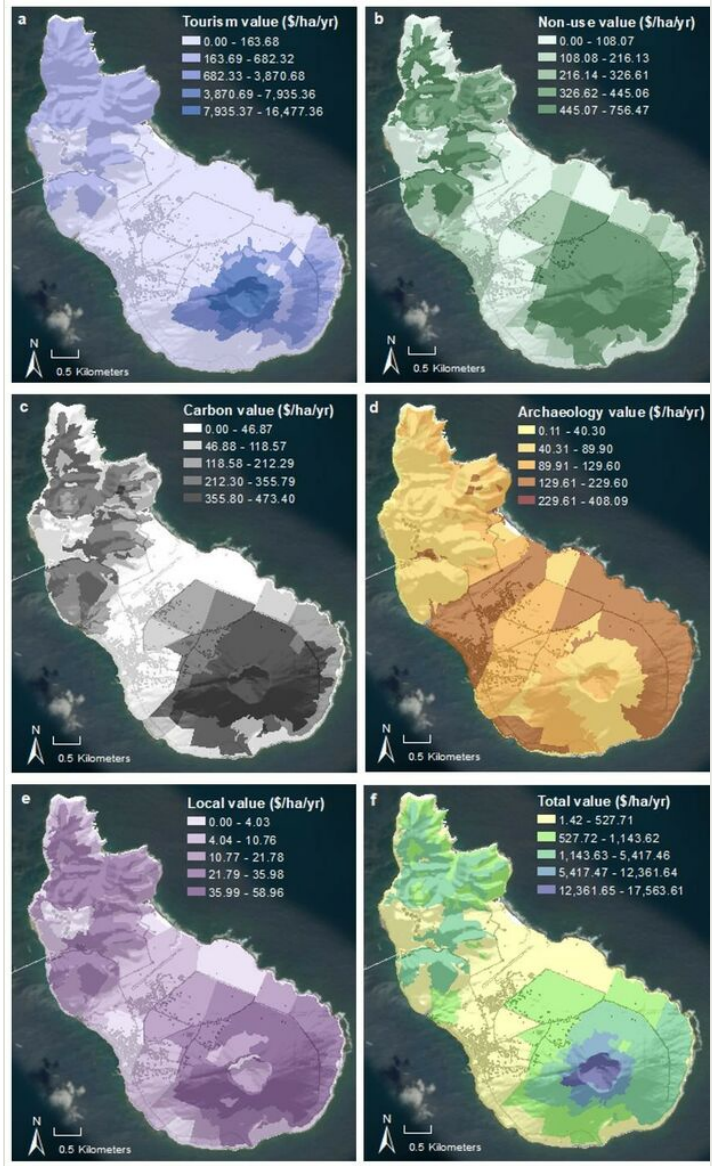

Figure 6.

Distribution of ecosystem service values in USD (2019) per hectare per year for the $0 \%$ Coralita cover scenario on the Island of St. Eustatius. 


\section{Results}

\section{$0 \%$ scenario}

Of all ecosystem services, the largest component was the tourism value (Table 2). The total tourism value of $\$ 1.2$ million per year was concentrated mainly on the Quill and in Boven National Park, with values ranging from $\$ 0$ to $\$ 16,477 / \mathrm{ha} / \mathrm{yr}$ (Fig. 6a). The Cultuurvlakte received solely low values and the highest value belonged to the crater of the Quill volcano.

The second largest value was the non-use value, with a total amount of $\$ 751,298$ per year (Table 2). This amount was more evenly distributed over the Island than the tourism value, spanning a range from $\$ 0$ to $\$ 756 / \mathrm{ha} / \mathrm{yr}$ (Fig. 6b). The higher values were mostly represented by the National Park areas of Boven and the Quill, extending partly onto the Cultuurvlakte from the Quill towards the centre of the Island. The north-western part of Oranjestad and its neighbouring beach yielded higher values than most beaches on the Island.

The carbon value ranged from $\$ 0$ to $\$ 473 / \mathrm{ha} / \mathrm{yr}$ and its distribution clearly represented the mean tree cover pattern (Fig. 6c) (Suppl. material 1). Accordingly, the forests on the Quill and in Boven National Park generated the highest values. The yearly value amounted to $\$ 410,625$ (Table 2).

Archaeology showed a unique geographic pattern compared to the other services, with values peaking mainly on the Cultuurvlakte and at the bottom of the north-eastern Quill slopes (Fig. 6d). Each value level was slightly lower than for carbon, ranging from $\$ 0.1$ to $\$ 408 / \mathrm{ha} / \mathrm{yr}$. With a total yearly value of $\$ 285,445$, archaeology was the fourth contributor to the total economic value (Table 2).

The smallest ecosystem service value was the local cultural and recreational value, ranging from $\$ 0$ to $\$ 59 / \mathrm{ha} / \mathrm{yr}$. The total value of $\$ 41,315$ was mainly concentrated on the slopes of the Quill and in Boven National Park (Fig. 6e) (Table 2).

The sum of all ecosystem service values amounted to a total economic value of $\$ 2.7$ million per year (Table 2). The highest values per hectare were clearly located on the crater of the Quill (\$12,362 - \$17,564), indicating the significance of the volcano for the Island's ecosystem services. Mid-range values were distributed on the volcano's flanks and in Boven National Park (\$528 - \$5,417) and the lower values appeared mainly on the Cultuurvlakte, around the oil terminal and on the south-western beach areas (Fig. 6f).

\section{$3 \%$ scenario}

The total loss of ecosystem service values under the $3 \%$ scenario was $\$ 39,804$ per year (Table 2 ), which was $1.5 \%$ of the total value under the $0 \%$ scenario. This loss was largely driven by the reduction of the non-use value, that accounted for $45 \%$ of the total loss and reached ca. \$100/ha/ yr in two areas on the northern base of the Quill (Fig. 7b) (Table 2). These areas also showed the highest total value loss (up to $\$ 183 / \mathrm{ha} / \mathrm{yr}$ ) and belonged to 
the highest loss category for carbon, archaeology and the local value (Fig. 7c-e). The 3\% cover pattern affected the tourism value only on the slopes of the Quill, which accounted for a relatively large overall loss on the eastern flank (Fig. 7a,f). Despite the low Coralita abundance on the western slopes of the Quill, there was still a considerable overall loss because all ecosystem services, other than archaeology, were affected. A smaller area with severe impact was near a trail end on the west coast, just below the hills of Boven (Fig. 7f). The high density of Coralita at this location resulted in high-end losses for carbon and archaeology values (Fig. 7c,d). The areas least affected by Coralita presence under this scenario were a portion of the Cultuurvlakte towards the east coast and around the oil terminal (Fig. 7a-f).
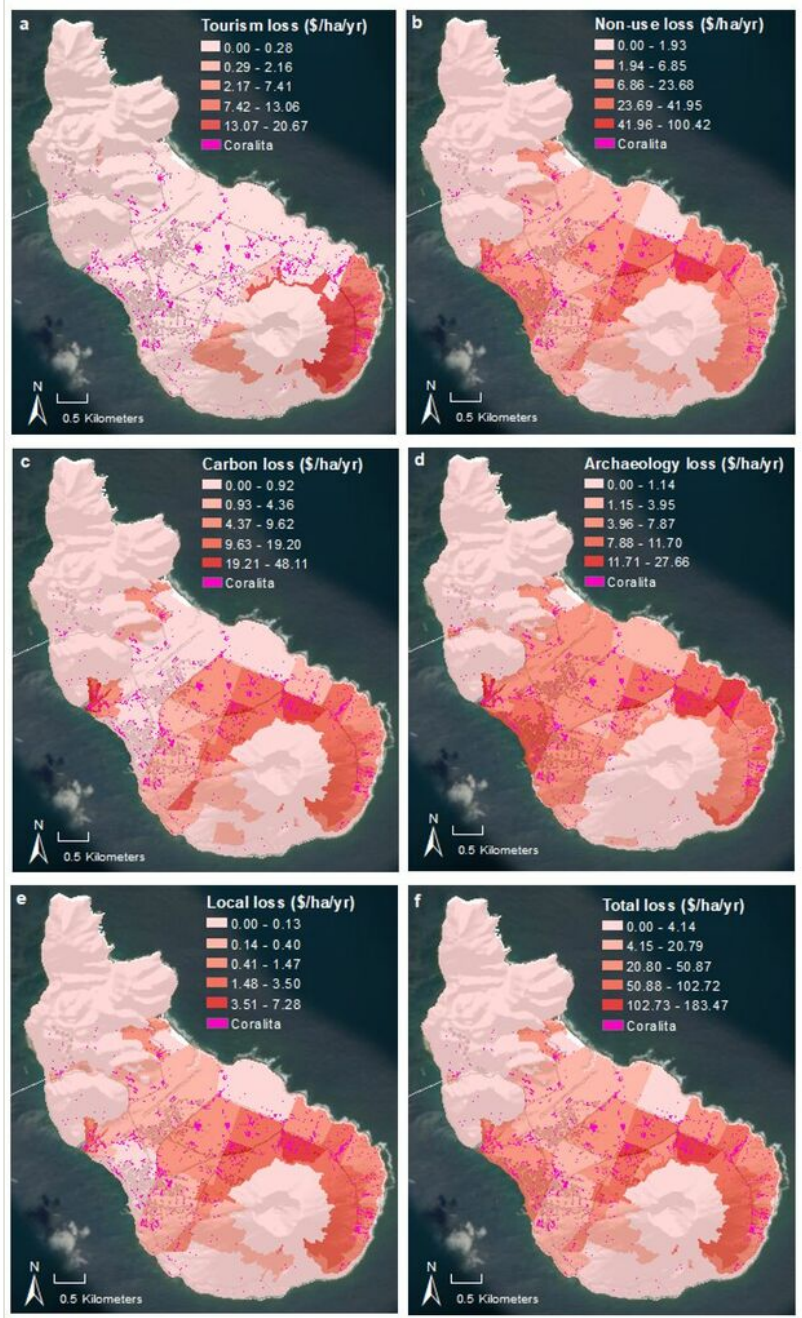

Figure 7.

Distribution of the loss of ecosystem service values in USD (2019) per hectare per year for the $3 \%$ Coralita cover scenario on the Island of St. Eustatius. 


\section{$36 \%$ scenario}

This scenario demonstrated a substantial loss of all ecosystem services, amounting to a total yearly loss of $\$ 576,704$ (Table 2). This is a $21.2 \%$ loss of the total economic value under the $0 \%$ scenario. Similar to the $3 \%$ scenario, the ecosystem service with the largest loss was the non-use value. However, losses were more evenly distributed, with tourism, carbon and archaeology values largely contributing as well (Table 2). The highest loss per hectare occurred in the tourism value, with losses up to $\$ 661 / \mathrm{ha} / \mathrm{yr}$ on the eastern slopes of the Quill (Fig. 8a). This was reflected in the total loss map, where a major part of the eastern flank fell into the highest loss category (Fig. 8f). With losses between $\$ 769$ and $\$ 1,256 / \mathrm{ha} / \mathrm{yr}$, this category also extended further onto the Cultuurvlakte and towards the north-western slopes of the Quill (Fig. 8f). On the southern slope, an area with losses between $\$ 42$ and $\$ 119 / \mathrm{ha} / \mathrm{yr}$ occurred, whereas the 3\% scenario only caused a negligible loss at this site $(<\$ 4 /$ ha/yr) (Fig. 7f) (Fig. 8f).
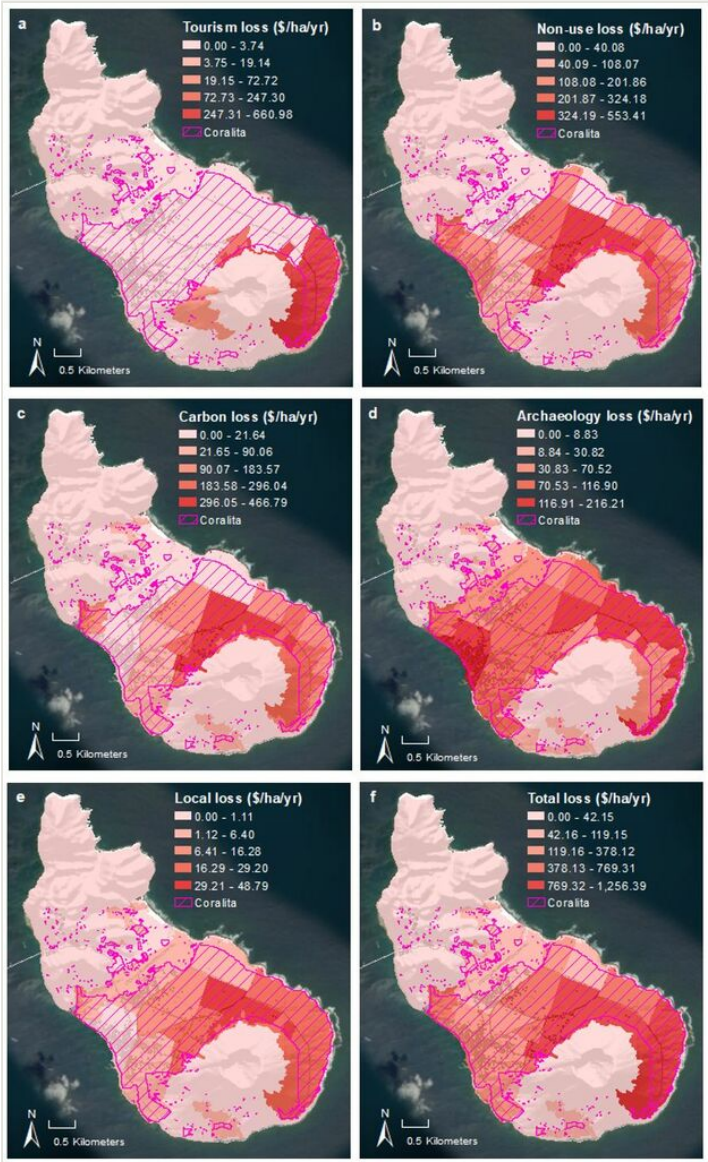

Figure 8.

Distribution of the loss of ecosystem service values in USD (2019) per hectare per year for the $36 \%$ Coralita cover scenario on the Island of St. Eustatius. 


\section{Discussion}

\section{Interpreting total ecosystem service values and losses}

The total value of the five main ecosystem services of St. Eustatius included in this study was $\$ 2.7$ million per year for the $0 \%$ scenario (unaffected by Coralita) (Table 2). This is $2.7 \%$ of St. Eustatius' Gross Domestic Product (GDP) (CBS 2018). The 3\% and 36\% dominant Coralita cover scenarios caused a total loss of $\$ 39,804$ and $\$ 576,704$ per year, respectively (Table 2 ). The $36 \%$ scenario loss accounts for $0.6 \%$ of the GDP. The only former studies directly relating the economic costs of invasive species to the national GDP found a loss of $1.36 \%$ in China and $1.37 \%$ in the United States (US); however, both estimates were based on the effects of all nationally-occurring invasive species combined (283 for China and 50,000 for the US) (Pimentel et al. 2005, Xu et al. 2006). This shows that the loss of $0.6 \%$ GDP resulting from only one invasive species in our study is a relatively major impact.

Moreover, since we included only five terrestrial ecosystem services, our estimate of the total value and subsequently the total value loss due to Coralita was very conservative. Considering all ecosystem services, including those provided by the marine system, which have shown to make up the largest share of ecosystem service values on St. Eustatius (Cado van der Lely et al. 2014), would further increase the proportion of the total value loss in relation to the GDP of the Island. Although Coralita is a terrestrial species, it likely also affects the marine environment through run-off and sedimentation. Coralita presence shows a positive trend towards increased erosion rates (Jesse et al., in prep) and, especially on steep slopes, eroded soils rapidly enter lowland watersheds, eventually ending up in the ocean (Haber et al. 2016, Haber et al. 2021). Increased sedimentation has a negative impact on the balance of coral reef ecosystems by promoting algal growth (Debrot and Sybesma 2000) and reducing herbivory (Bellwood and Fulton 2008), which favours the algae in their competition with corals. This, in turn, reduces the overall diversity of the system and reduces its resilience to disturbances (Nyström et al. 2000). A degraded marine environment is detrimental for the diving industry, which makes up the largest part of the tourism value on St. Eustatius (Kerkhof et al. 2014). Diving and snorkelling are primary reasons to visit the Island for many tourists, so a substantial decline in tourism value is expected upon degradation of the coral reef. The main diving area is located just off the west coast, in line with the western slopes of the Quill (Suppl. material 5). Therefore, this area of the reef may easily be affected by potential increased run-off due the presence of Coralita on the steep slopes. Ultimately, it should be realised that the effects of Coralita extend beyond the terrestrial environment and probably cause far more comprehensive damage than we demonstrated in monetary values in this study.

Besides not being able to include all ecosystem services provided on and around the Island in this study, another point to consider is the difference in data accuracy and timing of the ecosystem service valuation and distribution methods. Values based on the studies from 2014 were updated where possible, for example, adjusted to the recent number of inhabitants on the Island; however, there was still an unavoidable variation amongst data 
layers ranging from 2013 to 2019 . For instance, for carbon sequestration, the combination of most accurate and most recent data resulted in tree cover data from 2013 and carbon prices from 2019 and the spatial distribution of the non-use value was built on species data from varying years. This variance could result in different outcome values should the studies be repeated today, especially with highly volatile parameters, such as the carbon market price. However, we expect most valuation methods to be relatively stable, as we see no reason to assume that people drastically changed their attitude towards nature valuation. Moreover, it could be assumed that people are more willing to pay for nature now that climate change and habitat degradation become more visible, both in the direct surrounding and on the global agenda (Gärtner and Schoen 2021). Again, this would point towards an underestimation of the ecosystem service values and hence losses caused by Coralita.

\section{Spatial distribution patterns}

The initial distribution of values ( $0 \%$ scenario) mainly corresponded to the distribution of forest cover, with higher values in the National Park areas and especially in the Quill crater (Fig. 6f) (Suppl. material 1). This demonstrates how most ecosystem services are linked to the more pristine ecosystems, giving value to the greener, less urbanised areas. Only archaeological values and some local values showed different patterns, giving more value to the Cultuurvlakte. This can be explained by the locations of archaeological sites in the urban areas and the probability of findings that was higher on most beaches according to the ARGEOgraph map (Fig. 6d). Although most of the Quill is covered in equally dense forest, the crater and crater rim generated much higher values than the slopes (Fig. 6f). This was driven by the peak values of tourism in the crater (Fig. 6a), since visiting the crater is one of the main attractions on the Island. Furthermore, the crater is home to endemic plant and bird species and contains rare primary forest habitat. Ultimately, the centre of the Quill volcano is the most economically valuable part of St. Eustatius' ecosystem.

Under both Coralita cover scenarios (3\% and 36\%), the highest losses were concentrated on the slopes of the Quill. Given the initial distribution of ecosystem service values $(0 \%$ scenario) with the highest values covering the Quill, this pattern seems plausible. In the $3 \%$ scenario, the non-use value made up the largest component of the total loss (Table 2). This means that the total loss of the $3 \%$ scenario was mostly due to the negative impacts of Coralita on the biodiversity that (mainland) Dutch inhabitants are willing to pay for. For the two highest loss areas, at the northern base of the Quill (Fig. 7b,f), this is explained by the density of dominant Coralita cover patches concentrated in highly biodiverse areas. In these areas, apart from smothering native vegetation, Coralita overgrows (potential) nesting sites in the habitat of birds and iguanas. The Lesser Antillean Iguana (Iguana delicatissima) is an iconic and critically-endangered species (IUCN Red List 2018). The decline of a single species may seem a local ecological event; however, it can extend to the ecosystem service level and ultimately shrink the large amount of money from Dutch mainland inhabitants that St. Eustatius could receive for its nature. 
The $36 \%$ scenario demonstrated a much higher loss of tourism values than the $3 \%$ scenario. Although the total yearly loss was still highest in the non-use value, the tourism value showed the largest loss in hectares per year: up to $\$ 661 / \mathrm{ha} / \mathrm{yr}$ (Fig. 8a). This is an important result because the Island's economy is highly dependent on tourism. The Strategic Development Plan for the Island (Koene 2010) also includes strategies to further develop the tourism industry for economic purposes. Our study shows that the threat of Coralita should be seriously considered in relation to tourism, because it can have a large impact on tourism numbers, expenditure and their WTP for the environment. Tourists have indicated that hiking and the natural landscape are amongst the most enjoyed features of their Island visit; few tourists visit the Island without hiking trails in the National Parks (Kerkhof et al. 2014). It should be recognised that especially the popular trails on the Quill volcano will rapidly lose their attraction if Coralita dominates the landscape. Although diving is still the most enjoyed and profitable tourist activity (Kerkhof et al. 2014), degradation of the natural landscape will likely lead to tourists visiting another Caribbean island to enjoy the terrestrial landscape when they are not engaged in marine activities.

The loss in archaeological value is also linked to tourism, since tourists have indicated that visiting historical sites is their foremost terrestrial activity $(50 \%$ of all tourists visit historical sites, followed by $48 \%$ that take an Island tour by car and $40 \%$ that go hiking) (Kerkhof et al. 2014). They also firmly agreed with the statement that archaeological heritage should be promoted more. Although the WTP of tourists for archaeology management is part of the archaeological value in this study, this interest implies that a decline in accessible archaeological heritage may also negatively affect overall tourism appreciation for terrestrial activities on the Island.

\section{Scenario validity}

The difference between the annual loss under the $3 \%$ and $36 \%$ Coralita cover scenario is larger than the proportional difference in Coralita cover $(1.5 \%$ and $21 \%$ of the total value, respectively). This results partly from the assumed extent of the damage that increases with the extent of the invasion: large, monospecific carpets of Coralita are more likely to completely smother trees and degrade habitats, whereas smaller, sparsely distributed patches allow for a more diverse landscape, more light to penetrate and more space to use for nesting and foraging by animals. Furthermore, it is explained by the difference in affected areas. Considering the Quill area, the most economically-valuable region of the landscape, we see Coralita literally creeping up the slopes. The further it progresses, the higher the losses will be. The obvious questions are: what is the current situation and how realistic are the estimated losses?

The current situation lies in between the two scenarios: using the rate of spread estimated by Berkowitz (2014), the minimal dominant cover is likely $\sim 6 \%$ in 2021 . This is probably still an underestimate, because the remote sensing method cannot detect Coralita when it grows underneath the canopy (Haber et al. 2021). Besides, all effects from subdominant cover are not included in this scenario. The assumptions made to estimate the loss under different scenarios are hypothetical rather than empirical. However, the direction of the effects is often a solid case based on observation or literature and, therefore, we consider 
the estimates a valid approach to demonstrate the impact of Coralita on the included ecosystem services.

When estimating the increase of Coralita cover over time, it should also be noted that exogenous factors will likely favour Coralita growth, i.e. abiotic influences like the current warming trend in temperature and the occurrence of hurricanes (Heger and van Andel 2019). With abiotic stress, native plant communities generally become less resilient, resulting in competitive advantage for exotic species (Bullard 2010). Disturbances that cause canopy openings, such as lightning or hurricanes, create suitable conditions for pioneer invasive species like Coralita (Debrot and Bugter 2010, Eppinga and Pucko 2018). With a predicted increase in hurricane intensity (IPCC 2014) and the location of St. Eustatius in the Caribbean hurricane belt, Coralita may well be favoured (again) by hurricane events in the near future (Eppinga and Pucko 2018).

\section{Priority areas}

Our study provides a clear image of the areas where Coralita is causing the highest losses in total economic ecosystem service values. The analysis can help define the priority areas for Coralita management and, furthermore, serve to balance costs and benefits of removal versus lost ecosystem service values. While the costs of complete Coralita removal have yet to be defined, it is evident that the costs become disproportionally higher with increasing Coralita cover (Jesse et al., in prep). Furthermore, the recently-developed model by Eppinga et al. (2021) suggests that removal strategies focusing on smaller, more isolated patches would be most effective. Therefore, targeting these specific patches in an early succession state is likely to have a strong positive effect on the cost-benefit balance.

For almost all ecosystem service values, the Quill volcano yields the highest value, especially on the northern and eastern slopes. Coralita has slowly been progressing up the slopes for years, although it seems to have an elevational threshold around 150-200 metres above sea-level (masl) (Ernst and Ketner 2007; Berkowitz 2014). This may be due to the increased angle of the slopes, a change in soil properties or the fact that the vegetation on the higher slopes of the Quill is still too dense and resilient for invasion (Ernst and Ketner 2007). However, nowadays Coralita can already be found occasionally above 200 masl and has also shown to be capable of smothering dense, natural vegetation at elevations around 100 masl. Therefore, the slopes of the Quill should be a priority area to stop Coralita from progressing further up into the healthy forests of the volcano. In combination with the results of the model by Eppinga et al. (2021) that show removal strategies focusing on smaller, more isolated patches would be most effective, targeting exactly those type of patches on the slopes of the Quill should provide optimal results.

\section{Conclusions}

While monitoring and evidence of the negative effects of Coralita on St. Eustatius started more than a decade ago, no rigorous measures have been taken yet. We hope that the minimal economic loss of $\$ 39,804$ per year and future expectancy of $\$ 576,704$ per year 
due to Coralita presence are a wake-up call to realise the threat of this invasive species to the economy of the Island. The economic losses in ecosystem service values and, more importantly, their spatial distribution, will hopefully form a basis for prioritised management strategies and promote urgent action to tackle the major problem of Coralita that St. Eustatius is currently facing. We recommend future research efforts to focus specifically on making a cost-benefit analysis of Coralita removal from isolated patches in the defined priority areas, as this would greatly contribute to the design of management strategies.

\section{Acknowledgements}

We would like to thank Elizabeth Haber for providing the remotely sensed Coralita cover data and her valuable input.

\section{Funding program}

Netherlands Organization for Scientific Research (grant number: 858.14.041)

\section{Grant title}

Island biogeography meets the Anthropocene

\section{Hosting institution}

Not Applicable

\section{Ethics and security}

Not Applicable

\section{Author contributions}

JE, PB and WJ conceived the study; SH developed the methodology and curated and analysed the data in consultation with $\mathrm{WJ}$; JE and PB supervised the project; $\mathrm{SH}$ wrote the manuscript, which was reviewed and commented on by all authors.

\section{Conflicts of interest}

The authors declare no conflict of interest. 


\section{References}

- $\quad$ ARGEOgraph (2013) argeograph.nl/project/eustatius2013/eustatius2013 a3map.pdf

- Baccini A, Walker W, Carvalho L, Farina M, Sulla-Menashe D, Houghton RA (2017) Tropical forests are a net carbon source based on aboveground measurements of gain and loss. Science 358 (6360): 230-234. https://doi.org/10.1126/science.aam5962

- Bax N, Williamson A, Aguero M, Gonzalez E, Geeves W (2003) Marine invasive alien species: a threat to global biodiversity. Marine Policy 27 (4): 313-323. https://doi.org/ 10.1016/s0308-597x(03)00041-1

- Bellard C, Cassey P, Blackburn T (2016) Alien species as a driver of recent extinctions. Biology Letters 12 (4). https://doi.org/10.1098/rsbl.2015.0623

- Bellwood D, Fulton C (2008) Sediment-mediated suppression of herbivory on coral reefs: Decreasing resilience to rising sea-levels and climate change? Limnology and Oceanography 53 (6): 2695-2701. https://doi.org/10.4319/lo.2008.53.6.2695

- Berkowitz B (2014) The state of Antigonon leptopus (Corallita) on St Eustatius in 2014. STENAPA, Gallows Bay, St. Eustatius. URL: https://www.dcbd.nl/sites/default/files/ documents/2014\%20Corallita\%20Report\%20Briana\%20Berkowitz\%20FINAL.pdf

- $\quad$ Beukering Pv, Brouwer R, Schep S, Wolfs E, Brander L, Ebanks-Petrie G, Austin T (2014) The impact of invasive species on tourism. Institute for Environmental Sciences, Vrije Universiteit Amsterdam. URL: http://www.wolfscompany.com/wp-content/uploads/ 2016/02/R14-32-Tourism-value-and-lionfish-final-report.pdf

- $\quad$ Beukering PV, Wouter Botzen WJ, Wolfs E (2012) IVM Institute for Environmental Studies The non-use value of nature in the Netherlands and the Caribbean Netherlands. URL: https://www.dcbd.nl/sites/default/files/documents/R12-07\%20 Non\%20use \%20value\%20BES\%20lslands.pdf

- Bos OG, Bakker PA, Henkens RJ, de Freitas JA, Debrot AO (2018) Preliminary checklist of extant endemic species and subspecies of the windward Dutch Caribbean (St. Martin, St. Eustatius, Saba and the Saba Bank). Wageningen Marine Research report https://doi.org/10.18174/460388

- Bullard JM (2010) Critical Situation Analysis (CSA) of Invasive Alien Species (IAS) Status and Management. Ministry of Agriculture, Lands, Forestry and Fisheries (MALFF). URL: http://caribbeaninvasives.org/wp-content/uploads/2011/06/CSA-finalversion-of-2011.pdf

- $\quad$ Burg WJvd, Freitas Jd, Debrot AO, Lotz LA (2012) Naturalised and invasive alien plant species in the Caribbean Netherlands: status, distribution, threats, priorities and recommendations. Wageningen, Foundation DLO Research Institute Plant Research International. URL: https://library.wur.nl/WebQuery/wurpubs/fulltext/198282

- Burke J, DiTommaso A (2017) Corallita (Antigonon leptopus): Intentional Introduction of a Plant with Documented Invasive Capability. Invasive Plant Science and Management 4 (3): 265-273. https://doi.org/10.1614/ipsm-d-10-00088.1

- $\quad$ Burslem DR, Whitmore T (1999) Species diversity, susceptibility to disturbance and tree population dynamics in tropical rain forest. Journal of Vegetation Science 10 (6): 767-776. https://doi.org/10.2307/3237301

- $\quad$ Cado van der Lely JA, Warning AE, Schep SW, van Beukering P, Wolfs E (2014) The Total Economic Value of Nature on St Eustatius. Institute for Environmental Studies. 
URL: https://www.dcbd.nl/sites/default/files/documents/R14-12-The-total-economicvalue-of-nature-on-St-Eustatius_0.pdf

- $\quad$ CBS (2018) https://www.cbs.nl/en-gb/figures/detail/83776ENG.

Accessed on: 2019-6-28.

- $\quad$ CBS (2019) https://www.cbs.nl/en-gb/figures/detail/84757ENG?q=Sint\%20Eustatius. Accessed on: 2019-6-02.

- Chaffin B, Garmestani A, Angeler D, Herrmann D, Stow C, Nyström M, Sendzimir J, Hopton M, Kolasa J, Allen C (2016) Biological invasions, ecological resilience and adaptive governance. Journal of Environmental Management 183: 399-407. https://doi.org/10.1016/j.jenvman.2016.04.040

- Chamber of Commerce \& Industry (2016) http://www.statiasabachamber.com/ statiasaba/economy/economic-sectors. Accessed on: 2019-4-16.

- $\quad$ Chapin FS, Eviner VT (2014) Biogeochemical Interactions Governing Terrestrial Net Primary Production. Treatise on Geochemistry189-216. https://doi.org/10.1016/ b978-0-08-095975-7.00806-8

- Clavero M, Brotons L, Pons P, Sol D (2009) Prominent role of invasive species in avian biodiversity loss. Biological Conservation 142 (10): 2043-2049. https://doi.org/10.1016/ j.biocon.2009.03.034

- Crowl TA, Crist TO, Parmenter RR, Belovsky G, Lugo AE (2008) The spread of invasive species and infectious disease as drivers of ecosystem change. Frontiers in Ecology and the Environment 6 (5): 238-246. https://doi.org/10.1890/070151

- Dawson W, Moser D, van Kleunen M, Kreft H, Pergl J, Pyšek P, Weigelt P, Winter M, Lenzner B, Blackburn T, Dyer E, Cassey P, Scrivens S, Economo E, Guénard B, Capinha C, Seebens H, García-Díaz P, Nentwig W, García-Berthou E, Casal C, Mandrak N, Fuller P, Meyer C, EssI F (2017) Global hotspots and correlates of alien species richness across taxonomic groups. Nature Ecology \& Evolution 1 (7).

https://doi.org/10.1038/s41559-017-0186

- Debrot AO, Sybesma J (2000) Seas at the millennium: an environmental evaluation. Flanders Marine Institute. URL: http://www.vliz.be/en/imis?refid=4515

- Debrot AO, Bugter R (2010) Climate change effects on the biodiversity of the BES islands. Alterra Report1-39.

- De Deyn G, Cornelissen JC, Bardgett R (2008) Plant functional traits and soil carbon sequestration in contrasting biomes. Ecology Letters 11 (5): 516-531. https://doi.org/ 10.1111/j.1461-0248.2008.01164.x

- de Freitas J, Rojer A, Nijhof BSJ, Debrot A (2012) A landscape Ecological vegetation map of Sint Eustatius (Lesser Antilles). Koninklijke Nederlandse Akademie van Wetenschappen3-3.

- de Lange W, van Wilgen B (2010) An economic assessment of the contribution of biological control to the management of invasive alien plants and to the protection of ecosystem services in South Africa. Biological Invasions 12 (12): 4113-4124.

https://doi.org/10.1007/s10530-010-9811-y

- Duron Q, Bourguet E, De Meringo H, Millon A, Vidal E (2017) Invasive rats strengthen predation pressure on bird eggs in a South Pacific island rainforest. Current Zoology 63 (6): 583-590. https://doi.org/10.1093/cz/zox009

- $\quad$ Ehrenfeld J (2003) Effects of Exotic Plant Invasions on Soil Nutrient Cycling Processes. Ecosystems 6 (6): 503-523. https://doi.org/10.1007/s10021-002-0151-3 
- Eppinga M, Pucko C (2018) The impact of hurricanes Irma and Maria on the forest ecosystems of Saba and St. Eustatius, northern Caribbean. Biotropica 50 (5): 723-728. https://doi.org/10.1111/btp.12600

- $\quad$ Eppinga M, Baudena M, Haber E, Rietkerk M, Wassen M, Santos M (2021) Spatially explicit removal strategies increase the efficiency of invasive plant species control. Ecological Applications 31 (3): 1-13. https://doi.org/10.1002/eap.2257

- $\quad$ Ernst JJ, Ketner P (2007) Study on the ecology and possible control methods of the invasive plant species Antigonon leptopus (Corallita or Mexican Creeper). Dutch Caribbean Biodiversity Database (March)38-38. URL: https://www.dcbd.nl/document/ final-report-corallita-pilot-project-study-ecology-and-possible-control-methods-invasive

- Esteban N, Laloë J, Kiggen FPL, Ubels S, Becking L, Meesters E, Berkel J, Hays G, Christianen MA (2018) Optimism for mitigation of climate warming impacts for sea turtles through nest shading and relocation. Scientific Reports 8 (1). https://doi.org/ 10.1038/s41598-018-35821-6

- $\quad$ Fenkl F, Laclé FA, Schep SW, Van Beukering PJH, Brander L, Wolfs E (2014) The local cultural and recreational value of nature on St Eustatius. Dutch Caribbean Biodiversity Database (June). URL: https://www.dcbd.nl/document/local-cultural-and-recreationalvalue-nature-st-eustatius

- Gandhi KK, Herms D (2009) Direct and indirect effects of alien insect herbivores on ecological processes and interactions in forests of eastern North America. Biological Invasions 12 (2): 389-405. https://doi.org/10.1007/s10530-009-9627-9

- Gärtner L, Schoen H (2021) Experiencing climate change: revisiting the role of local weather in affecting climate change awareness and related policy preferences. Climatic Change 167 https://doi.org/10.1007/s10584-021-03176-z

- Gimeno I, Vila M, Hulme P (2006) Are islands more susceptible to plant invasion than continents? A test using Oxalis pes-caprae L. in the western Mediterranean. Journal of Biogeography 33 (9): 1559-1565. https://doi.org/10.1111/j.1365-2699.2006.01525.x

- Haber E, Vaas J, Eppinga M, Laerhoven FV, Rietkerk M, Giezen M, Driessen P, Wassen $M(2016)$ The social and ecological contexts of invasive plant management in the Caribbean Project Aim : Facilitate Decision Making. Utrecht University 325 (2009): 5939-5939. URL: http://posters.geo.uu.nl/2016/The social and ecological contexts of invasive_plant_management_in_the_Caribbean-Haber_Vaas_Eppinga vanLaerhoven Rietkerk Giezen Driessen Wassen-February2016.pdf

- Haber E, Santos M, Leitão P, Schwieder M, Ketner P, Ernst J, Rietkerk M, Wassen M, Eppinga M (2021) High spatial resolution mapping identifies habitat characteristics of the invasive vine Antigonon leptopuson St. Eustatius (Lesser Antilles). Biotropica 53 (3): 941-953. https://doi.org/10.1111/btp.12939

- Haines-Young R, Potschin-Young M (2018) Revision of the Common International Classification for Ecosystem Services (CICES V5.1): A Policy Brief. One Ecosystem 3 https://doi.org/10.3897/oneeco.3.e27108

- Hansen MC, Potapov PV, Moore R, Hancher M, Turubanova SA, Tyukavina A, Thau D, Stehman SV, Goetz SJ, Loveland TR, Kommareddy A, Egorov A, Chini L, Justice CO, Townshend JRG (2013) High-Resolution Global Maps of 21st-Century Forest Cover Change. Science 342 (6160): 850-853. https://doi.org/10.1126/science.1244693

- Heger WT, van Andel T (2019) A social-ecological perspective on ecosystem vulnerability for the invasive creeper coralita (Antigonon leptopus)in the Caribbean: A 
review. Global Ecology and Conservation 18: 1-11. https://doi.org/10.1016/j.gecco. 2019.e00605

- Hulme P (2009) Trade, transport and trouble: managing invasive species pathways in an era of globalization. Journal of Applied Ecology 46 (1): 10-18. https://doi.org/10.1111/ j.1365-2664.2008.01600.x

- Invasive Species Compendium (2019) Antigonon leptopus (coral vine). https://www.cabi.org/isc/datasheet/112316. Accessed on: 2019-5-02.

- $\quad$ IPCC (2014) Climate Change 2013 - The Physical Science Basis: Working Group I Contribution to the Fifth Assessment Report of the Intergovernmental Panel on Climate Change. IPCC1-1552. URL: http://zoobank.org/2c4e8e2e-4315-4a15-9d04-0b37 6fb53b8e

- $\quad$ IUCN Red List (2018) https://www.iucnredlist.org/species/10800/122936983. Accessed on: 2019-6-05.

- Jesse WM, Molleman J, Franken O, Lammers M, Berg M, Behm J, Helmus M, Ellers J (2020) Disentangling the effects of plant species invasion and urban development on arthropod community composition. Global Change Biology 26 (6): 3294-3306.

https://doi.org/10.1111/gcb.15091

- Kerkhof Svd, Schep S, Beukering Pv, Brander L (2014) The tourism value of nature on saba and statia: Using a choice modelling method. Institute for Environmental Studies. URL: https://www.dcbd.nl/document/tourism-value-nature-st-eustatius

- Koene A (2010) Sint Eustatius Strategic Development Pla. https://issuu.com/ alexanderkoene/docs/statia strategic plan

- Leeuw Sd (2014) A study on the growing conditions, distribution andpropagation of Ipomoea sphenophylla on Sint Eustatius. Dutch Caribbean Biodiversity Dtabase. URL: https://www.dcbd.nl/document/study-growing-conditions-distribution-and-propagationstatia-morning-glory-ipomoea

- Lodge D, Shrader-Frechette K (2003) Nonindigenous Species: Ecological Explanation, Environmental Ethics, and Public Policy. Conservation Biology 17 (1): 31-37. https://doi.org/10.1046/j.1523-1739.2003.02366.x

- Mc Neely J (2001) Invasive species: a costly catastrophe formative biodiversity. Land Use and Water Resources Research 1 (2): 1-10. https://doi.org/10.22004/ag.econ. 47850

- Mortimer JA, Donnelly M (2008) Eretmochelys imbricata: Mortimer, J.A \& Donnelly, M. (IUCN SSC Marine Turtle Specialist Group). IUCN Red List of Threatened Species https://doi.org/10.2305/iucn.uk.2008.rlts.t8005a12881238.en

- Murphy PG, Lugo AE (1986) Ecology of Tropical Dry Forest. Annual Review of Ecology and Systematics 17 (1): 67-88. https://doi.org/10.1146/annurev.es.17.110186.000435

- NOAA (2015) https://library.noaa.gov/Collections/Digital-Docs/Foreign-Climate-Data/ Netherlands-Antilles-Climate-Data. Accessed on: 2019-5-17.

- Nyström M, Folke C, Moberg F (2000) Coral reef disturbance and resilience in a human-dominated environment. Trends in Ecology \& Evolution 15 (10): 413-417. https://doi.org/10.1016/s0169-5347(00)01948-0

- $\quad$ Overeem R, Riemens M (2018) Antigonon leptopus (coral vine). https://doi.org/ 10.1079/9781786392145.0000

- $\quad$ Peh KH, Balmford A, Birch J, Brown C, Butchart SM, Daley J, Dawson J, Gray G, Hughes FR, Mendes S, Millett J, Stattersfield A, Thomas DL, Walpole M, Bradbury R (2014) Potential impact of invasive alien species on ecosystem services provided by a 
tropical forested ecosystem: a case study from Montserrat. Biological Invasions 17 (1): 461-475. https://doi.org/10.1007/s10530-014-0743-9

- Pejchar L, Mooney H (2009) Invasive species, ecosystem services and human wellbeing. Trends in Ecology and Evolution 24 (9): 497-504. https://doi.org/10.1016/j.tree. 2009.03.016

- $\quad$ Pimentel D, Zuniga R, Morrison D (2005) Update on the environmental and economic costs associated with alien-invasive species in the United States. Ecological Economics 52 (3 SPEC. ISS.): 273-288. https://doi.org/10.1016/j.ecolecon.2004.10.002

- Polman N, Reinhard S, van Bets LJ, Kuhlman T (2016) Governance of ecosystem services on small islands: Three contrasting cases for St. Eustatius in the Dutch Caribbean. Island Studies Journal 11 (1): 265-284. URL: https://library.wur.nl/ WebQuery/wurpubs/503759

- Seebens H, Essl F, Dawson W, Fuentes N, Moser D, Pergl J, Pyšek P, van Kleunen M, Weber E, Winter M, Blasius B (2015) Global trade will accelerate plant invasions in emerging economies under climate change. Global Change Biology 21 (11): 4128-4140. https://doi.org/10.1111/gcb.13021

- $\quad$ Stelten R (2009) The Golden Rock. Seventeenth-and eighteenth-century metal buckles from Oranje Bay, St. Eustatius. Universiteit Leiden URL: https://studenttheses. universiteitleiden.nl/handle/1887/18755?solr nav\%5Bid\%5D=ae5972 ba74a0b532d176\&solr nav\%5Bpage $\% 5 \mathrm{D}=23 \&$ solr nav $\% 5$ Boffset $\% 5 \mathrm{D}=2$

- Tieskens K, Schep S, Beukering Pv, Beek I, Wolfs E (2014) Mapping the Economic Value of Ecosystems on St Eustatius. Institute for Environmental Sciences.

URL: https://www.dcbd.nl/sites/default/files/documents/R14-13-Value-mapping- ofnature-on-St-Eustatius.pdf

- Tyukavina A, Baccini A, Hansen MC, Potapov PV, Stehman SV, Houghton RA, Turubanova S, Goetz SJ (2018) Corrigendum: Aboveground carbon loss in natural and managed tropical forests from 2000 to 2012 (2015Environ. Res. Lett.10 074002). Environmental Research Letters 13 (10). https://doi.org/10.1088/1748-9326/aae31e

- Vaas J, Driessen PJ, Giezen M, van Laerhoven F, Wassen M (2017) Who's in charge here anyway? Polycentric governance configurations and the development of policy on invasive alien species in the semisovereign Caribbean. Ecology and Society 22 (4). https://doi.org/10.5751/es-09487-220401

- van Andel T, van der Hoorn B, Stech M, Arostegui SB, Miller J (2016) A quantitative assessment of the vegetation types on the island of St. Eustatius, Dutch Caribbean. Global Ecology and Conservation 7: 59-69. https://doi.org/10.1016/i.gecco.2016.05.003

- van den Bergh JC, Botzen WJ (2015) Monetary valuation of the social cost of $\mathrm{CO}_{2}$ emissions: A critical survey. Ecological Economics 114: 33-46. https://doi.org/10.1016/ j.ecolecon.2015.03.015

- $\quad$ van der Heijden GF, Powers J, Schnitzer S (2015) Lianas reduce carbon accumulation and storage in tropical forests. Proceedings of the National Academy of Sciences 112 (43): 13267-13271. https://doi.org/10.1073/pnas.1504869112

- Walsh J, Carpenter S, Van Der Zanden MJ (2016) Invasive species triggers a massive loss of ecosystem services through a trophic cascade. Proceedings of the National Academy of Sciences of the United States of America 113 (15): 4081-4085. https://doi.org/10.1073/pnas.1600366113 
- Wilson JB, Peet R, Dengler J, Pärtel M (2012) Plant species richness: the world records. Journal of Vegetation Science 23 (4): 796-802. https://doi.org/10.1111/j. 1654-1103.2012.01400.x

- $\quad$ Xu H, Ding H, Li M, Qiang S, Guo J, Han Z, Huang Z, Sun H, He S, Wu H, Wan F (2006) The distribution and economic losses of alien species invasion to China. Biological Invasions 8 (7): 1495-1500. https://doi.org/10.1007/s10530-005-5841-2

- Yurkonis K, Meiners S (2004) Invasion impacts local species turnover in a successional system. Ecology Letters 7 (9): 764-769. https://doi.org/10.1111/j.1461-0248. 2004.00636.x

\section{Supplementary materials}

\section{Suppl. material 1: Tree cover map St. Eustatius doi}

Authors: Hansen et al. (2013)

Data type: Map

Brief description: Distribution of tree cover on the Island of St. Eustatius (Hansen et al. 2013)

Download file $(67.63 \mathrm{~kb})$

\section{Suppl. material 2: Iguana sightings map St. Eustatius doi}

Authors: Kluskens B., Madden H. (2015)

Data type: Map

Brief description: Iguana sightings on the Island of St. Eustatius (purple dots)

Download file $(33.40 \mathrm{~kb})$

\section{Suppl. material 3: Important birding areas St. Eustatius doi}

Authors: Geelhoed S.C.V. (2013)

Data type: Map

Brief description: Important birding areas on the Island of St. Eustatius

Download file $(72.82 \mathrm{~kb})$

\section{Suppl. material 4: Morning Glory map St. Eustatius doi}

Authors: De Leeuw L. (2014)

Data type: Map

Brief description: Distribution map of Statia Morning Glory on the Island of St. Eustatius Download file $(84.26 \mathrm{~kb})$

\section{Suppl. material 5: Dive sites around St. Eustatius doi}

Authors: Caribdiveguide.com

Data type: Map

Brief description: Map of dive sites around the Island of St. Eustatius

Download file $(91.12 \mathrm{~kb})$ 